\title{
Assessment of Competitiveness of Agricultural Products in the Global Market: Regional Aspect
}

\author{
Charykova O.G.* \\ Scientific Research Institute of Economics and Organization \\ of the Agro-Industrial Complex \\ Voronezh, Russia \\ e-mail: chog@narod.ru
}

Pashuta A.O.

Scientific Research Institute of Economics and Organization of the Agro-Industrial Complex

Voronezh, Russia

\author{
Salnikova E.V. \\ Scientific Research Institute of Economics and Organization \\ of the Agro-Industrial Complex \\ Voronezh, Russia
}

\begin{abstract}
The paper addresses the issues of improving the methodological tools for assessing competitiveness and analyzing the export orientation of agricultural markets. The relevance of the study is determined by the new course of Russian agricultural policy aimed at increasing exports and strengthening competitive positions in the global market. The main objectives of the study are to assess the export orientation and competitiveness of agricultural products in the regions of the Russian Federation (RF), which are characterized by diverse export orientations and different levels of agricultural development due to regional variations in agroclimatic conditions and spatial heterogeneity. The study aims to identify and demonstrate the sectoral characteristics of the regions. The priority characteristics are not climatic and environmental or socio-economic conditions (in contrast to traditional approaches), but changes in the volume and structure of agricultural production, the agricultural export/import ratio, and investment volumes, which are affected by agricultural state policy. The study is based on the general scientific methodology, which includes the systematic approach and general scientific methods of cognition (dialectical, deduction, decomposition, methods of economic analysis and synthesis) to achieve the aim of the study. To attain the objectives, we calculated the export coefficients and determined the export priority and competitiveness of agricultural products in relation to the country and to individual areas of Central Black Earth (CBE) region. The methodological tools proposed in the study can be used as an integral part of monitoring the development of strategies and programs for the improvement of export-oriented agricultural sectors in agro-industrial regions.
\end{abstract}

Keywords - product competitiveness; agriculture; foreign agricultural policy; global market; export orientation; grain.

\section{INTRODUCTION}

Achievement of the priority aims to ensure the national interests in the global market is largely determined by the actual agricultural policy of export development, and depends on the foreign demand and saturation of the domestic market, the efficient use of the export potential of the agricultural industry and reserves to increase the competitiveness of agricultural products.

\author{
Chernysheva I.I. \\ Scientific Research Institute of Economics and Organization \\ of the Agro-Industrial Complex \\ Voronezh, Russia
}

To date, the increased competitiveness of agricultural products is crucial for the export development process. Therefore, a timely comprehensive assessment of various aspects of the competitiveness of agricultural products at the supranational, national regional level and at the level of an individual enterprise is essential for identifying reserves for its increase. Of particular importance for the positioning and strengthening of competitive positions in international agricultural markets is the competitiveness of agricultural products: both in general and by individual types.

The aim of this study is to improve the theoretical and methodological approaches to assessing the competitiveness of domestic agricultural products, to test the methodology and to identify trends in export development of the regions.

The study is based on the theoretical and methodological and methodical principles developed by foreign and domestic researchers, on the experience in development of international activities and competitiveness, on suggestions and recommendations that determine the priority trends, and on the ways and mechanisms to increase the competitiveness of agricultural products and regions in the global market.

\section{THEORETICAL BACKGROUND}

The constant development of foreign markets promoted the formation of numerous vectors of organization the effective international specialization of the countries. The authors of the mercantilist theory (T. Man, J.-B. Colbert, A. Moncretien, W. Stafford), the theory of absolute advantages (A. Smith), and the theory of comparative advantages (D. Riccardo, D.S. Mill) the theory of the ratio of factors of production (E. Heckscher, B. Olin) and others [1-4] contributed to the creation of the theoretical and methodological principles of international trade.

The theories are based on various factors that influence the effectiveness of international trade, such as absolute and comparative advantages, replacement costs, factors of production and specific factors of production, the ratio of factors of production, the life cycle of products, intraindustry international trade, economies of scale, competitive advantages, etc. 
A country's participation in international trade implies, first of all, the availability of competitive products that can be offered in foreign markets. Since the total volume of export products depends on the regions of the country, their competitiveness is the decisive factor for participation in international trade.

The theory of the competitiveness of individual regions appeared in the last decades of the twentieth century and developed by P. Krugman, M. Porter, D. Sachs and others. The interrelation of the region's competitiveness and products manufactured in the region was investigated by M. Gelvanovsky, R. Domansky, S. Emelyanov, I. Zubarevich, R. Kamani, M. Castels, G. Kulikov, A. Tatarkina, G. Untury, R. Fathutdinov, R. Shniper, and others. However, researchers continue to argue about the need and methods for assessing the region's competitiveness [1-4].

P. Krugman [2, 3] justifies the need to develop and implement the state international trade policy, which is aimed at achieving leading positions in the global market. This becomes possible on the basis of comprehensive state support for competitive industries. It is important to create favorable conditions for national producers to increase production volumes to the level that provides sufficient economies of scale consistent with global trends. In this case, it is essential to use advanced technologies in the production process $[5,6]$.

In the context of globalization, the development of the global market is based on export revenues and coverage of import needs [7]. The theoretical and methodological principles substantiating the principles of international trade explain the profitability of international trade and give an idea of the grounds for choosing the geography of international trade operations. International trade, as an instrument for the development of specialization, motivates countries to increase the competitiveness of products through increased productivity using limited resources [8]. This leads to the increased production of goods (services) and, as a result, to the improved well-being of the population.

The generalization and systematization of various theories revealed in a broad scientific understanding of the content of the international competitiveness of a country, region, and industry, which contributed to the formulation of the general hypothesis. It consists in the assumption that access to international agricultural markets with most effective products should not be the priority task to strengthen and further expand the country's position in the global market. In the context of globalization, it is necessary to take into account regional peculiarities when choosing the methods of state regulation of international trade in order to ensure the growth of competitiveness of national agricultural products at the world level [9-11]. Only a stable competitive position in foreign markets can ensure international competitiveness. This implies a timely assessment of the international competitiveness of products and the growth of international demand, the effective use of export potential, and increased competitiveness [12-14].

\section{MethodOLOGY}

A scientific study of competitiveness, which can be observed at the interregional level, determines the need to take into account this specificity for the formation of theoretical principles and the use of methodological tools.

The priority characteristics to assess competitiveness and determine sectoral characteristics are not the climatic and environmental or socio-economic conditions of the region (in contrast to traditional approaches), but changes in the volume and structure of agricultural production, the agricultural export/import ratio, and investment volumes, which depend on agricultural state policy $[15,16]$.

When analyzing the foreign agricultural policy, we evaluated indicators of the country's openness proposed by L.G. Matveeva, O.A. Chernova, V.V. Klimuk [17] in the methodological tools for assessing the effectiveness of the rational import substitution policy in industry and used by the Scientific and Research Financial Institute of the Ministry of Finance of Russia to develop indicators of the decreased dependence of the Russian economy on agrifood imports.

When improving the methodology, indicators of export orientation (priority, elasticity, load, opportunities) were taken into account, which enabled evaluation of the competitiveness indicator of agricultural products, detailed later on by its individual types (Table I).

TABLE I. INDICATORS OF EXPORT ORIENTATION OF THE AGRICULTURAL MARKET

\begin{tabular}{|l|l|}
\hline \multicolumn{1}{|c|}{ Indicator } & \multicolumn{1}{c|}{ Calculation } \\
\hline Import priority indicator & import growth rate / export growth rate \\
\hline Indicator of import load & $\begin{array}{l}\text { import volume / gross domestic product (GDP) } \\
\text { or regional regional product (GRP) x 100 \% }\end{array}$ \\
\hline Indicator of export priority & export growth rate / import growth rate \\
\hline Export elasticity indicator & export growth rate / GDP / GRP growth rate \\
\hline Export load indicator & $\begin{array}{l}\text { export volume / gross domestic product } \\
\text { (domestic regional product) x 100 \% }\end{array}$ \\
\hline Competitiveness indicator & export surplus / foreign trade x 100\% \\
\hline $\begin{array}{l}\text { Export market } \\
\text { opportunities (potential) }\end{array}$ & $\begin{array}{l}\text { potential market capacity - actual market } \\
\text { capacity; } \\
\text { production capabilities - domestic market } \\
\text { capacity }\end{array}$ \\
\hline
\end{tabular}

The competitiveness indicator may vary in the following range:

$$
-100<\mathrm{K}<100
$$

The increased $\mathrm{K}$ indicates the increased competitiveness and vice versa. A change in the indicator shows the direction of foreign economic activity (in case of excess goods, the price in the domestic market falls and export becomes more attractive; in case of shortage of goods in the domestic market, import is necessary).

\section{ANALYSIS}

The results of a problem-oriented analysis of the export orientation of the agricultural market showed positive trends in export growth and improvement of the competitiveness of agricultural products. In this regard, both quantitative and qualitative development of the agricultural market of the Russian Federation will be facilitated by growing export orientation. This is a very promising direction, since 
competitive products should be offered in foreign markets that facilitates intensive development of the agricultural sector of the economy [18]. In the analysis of export segments of the agricultural market, the priority is the analysis of international trade in food products and agricultural raw materials for the country and for individual regions and macroregions, as well as evaluation of its significance for the economy of the country and regions. To analyze the foreign economic activity of local agrifood markets and individual agricultural segments, it is necessary to consider the volumes of exports and imports, the volumes of international trade, commodity and geographical structure of exports, which contribute to the country's competitiveness.

In 2011-2017, the Russian Federation was characterized by the trade deficit, which nevertheless declines, while the export of food products and agricultural raw materials were observed to grow, which indicates an increasing international demand for domestic goods. The growing export of agricultural products in Russia and CBE region and its increased share in national and regional exports has been observed since 2011. Among the areas of CBE region, the largest export volume was noted in 2017 for Belgorod and Voronezh regions. At the same time, export volumes in 2017 exceeded those in 2011 by 2.8 times and 1.9 times, respectively. At the same time, the export load indicator observed for the study period shows that the agricultural economy of the regions is not sufficiently open (Table II).

TABLE II. ANALYSIS OF THE OPENNESS OF THE AGRICULTURAL MARKET OF MACROREGIONS

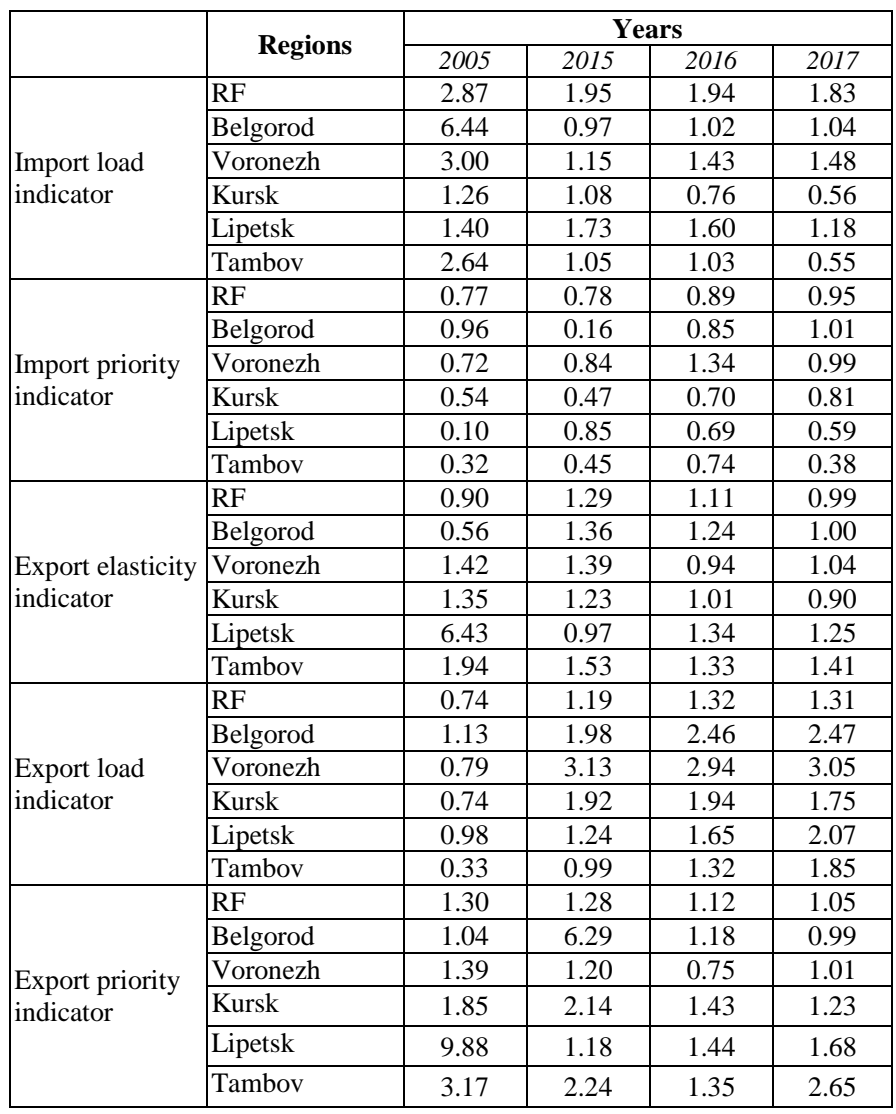

The export orientation of the agricultural sector of Russia is confirmed by the increased share of exports in the volume of domestic goods.

The analysis showed that the competitiveness indicator of agricultural products in Russia has been steadily increasing since 2013 (although it still remains negative), which shows the growing competitiveness of Russian agricultural products in foreign markets. Recently, the competitiveness indicator of grain, vegetable oil and sugar has been constantly increasing. This indicator demonstrates the steadiest growth in grain production competitiveness (Table III).

TABLE III. ASSESSMENT OF GRAIN COMPETITIVENESS

\begin{tabular}{|l|c|c|c|c|}
\hline \multirow{2}{*}{\multicolumn{1}{|c|}{ Indicators }} & \multicolumn{4}{c|}{ Years } \\
\cline { 2 - 5 } & $\mathbf{2 0 1 4}$ & $\mathbf{2 0 1 5}$ & $\mathbf{2 0 1 6}$ & $\mathbf{2 0 1 7}$ \\
\hline Grain import, mln dol. & 524 & 336 & 352 & 363 \\
\hline Grain export, mln dol. & 7060 & 5651 & 5610 & 7490 \\
\hline Grain cost, mln dol. & 19016 & 14594 & 14713 & 17054 \\
\hline Dollar to ruble rate & 36.6 & 62.3 & 73.2 & 59.2 \\
\hline Import load indicator & 0.0276 & 0.0230 & 0.0239 & 0.0213 \\
\hline Export load indicator & 0.3713 & 0.3872 & 0.3813 & 0.4392 \\
\hline Import growth rate & 0.8304 & 0.6412 & 1.0476 & 1.0313 \\
\hline Export growth rate & 1.4857 & 0.8004 & 0.9927 & 1.3351 \\
\hline Import priority indicator & 0.5590 & 0.8011 & 1.0553 & 0.7724 \\
\hline Export priority indicator & 1.7891 & 1.2483 & 0.9476 & 1.2947 \\
\hline Competitiveness indicator & 86.181 & 88.776 & 88.192 & 90.755 \\
\hline
\end{tabular}

Analysis of the competitive positions of Russian vegetable oil indicates a positive trend for 2013-2017. Insignificant changes in this indicator can be observed; however, it exceeds the level of grain and sugar competitiveness and demonstrates a fairly high value.

The soybean segment of the agricultural market characterized by high demand in the global market is quite promising.

\section{DISCUSSION}

The structural indicators of the development of international trade and improvement of competitiveness of domestic agricultural products are the commodity and geographical structure of exports [19].

The main components of the geographical structure of Russia's exports are the near abroad countries, that is Commonwealth of Independent States (CIS), and foreign countries. It should be noted that the volume of grain imports in 2000 exceeded exports by 3,325 thousand tons, and in 2017 grain exports exceeded imports by 42,548 thousand tons. Wheat and meslin make up the largest share of cereals: in $2000-43.9 \%$ (0.6 million tons), in 2017 - $76.4 \%$ (33 million tons). At the same time, in 2000, exports to the CIS countries (77.6 \% or 0.5 million tons) prevailed in the geographical structure of exports, whereas in 2017 , due to the favorable price situation in foreign markets, $95.4 \%$ (31.5 million tons) of wheat and meslin were exported to foreign countries.

In 2000, the price of wheat and meslin exported to the CIS countries amounted to $\$ 126 / t$, in $2010-\$ 192 /$ t thereby exceeding the price of these products to foreign countries by $\$ 41.8 / \mathrm{t}$ and $\$ 18 / \mathrm{t}$, respectively. In 2017 , the situation was slightly different: the average price of wheat and meslin export 
to foreign countries was $\$ 176 / t$, and the price for the CIS countries attained $\$ 10 / \mathrm{t}$.

The results of the study indicate that since 2014 the geographical structure of exports has changed. So, in particular, although slightly, the share of the CIS countries in the Russian export of food products and agricultural raw materials is decreasing. If in 2014 about $27 \%$ of Russian exports of food products and agricultural raw materials were sent to the CIS countries, in $2017-24 \%$.

In 2014, the largest export volumes of domestic agricultural products (40 \% of the total exports at the agricultural market) were observed in 5 countries: Turkey (12\%), Kazakhstan (9\%), Egypt (7\%), the Republic of Korea (6\%), and China (6\%). At the end of 2017, the list of the countries remained the same, but their positions changed in: the share of China increased to $9 \%$, and the share of Turkey, on the contrary, decreased to $8 \%$.

At the country level, the change in the physical volume of exports is largely associated with various external sanctions and limitations. Thus, the largest decrease in the volume of export and import operations of the Russian Federation was noted for Turkey, Poland, the Netherlands, France, Spain and some other EU countries, while exporting to Egypt, Vietnam, Lebanon, Bangladesh, China and some other countries was observed to grow [20].

One of the promising competitive advantages of domestic products is the increased grain production that is environmentally friendly, and therefore has a certain competitive advantage in foreign markets. There is an increased demand for these products from consumers in foreign markets [21, 22].

\section{CONCLUSION}

The following practically significant results have been obtained in the study.

1. A theoretical and methodological principles are developed based on a critical generalization of the works by foreign and Russian scientists focused on the development of international competition and increase of competitiveness. The principles synthesize the theory proposed by P. Krugman (on the need to achieve the leading position in the global market as an important condition for international competitiveness) and the theory proposed by M. Porter (on the competitive advantages and competitiveness of regions).

2. To analyze the export orientation of the national agricultural market and its regional segments in terms of $\mathrm{P}$. Krugman's trading theory, the methods for studying openness and competitiveness of markets are improved and tested at the level of the Russian Federation and at the level of Central Black Earth region.

3. Positive trends in the development of export orientation are identified for the areas of CBE region, which outperform all-Russian indicators for the share of agricultural products in total exports, trade surpluses, export load, export priority, competitiveness factors; the competitiveness indicators of certain types of products are determined for the areas of $\mathrm{CBE}$ region (grain, vegetable oil, sugar).
4. Over the study period, the growth of exports of food products and agricultural raw materials was observed in the areas of $\mathrm{CBE}$ region. The highest export indicator was noted for Lipetsk and Voronezh regions, which increased by 2.7 p.p. in 2017 compared to 1.6 p.p. in 2011. However, the export load indicator shows the lack of openness of the economy of the agricultural sector. The main export-oriented agricultural markets of Russia are the grain market and the market of fish and fish products. Numerous studies show a wide variety of components of the commodity and geographical structure of the Russian agrifood exports, which significance in the allRussian export activity is high. The relevance of the development and implementation of measures aimed at stimulating export activity is justified, and the need to increase exports of high-tech products that are competitive in foreign markets is established. The study shows that $\mathrm{CBE}$ region and the Russian Federation as a whole exhibit significant export potential in the grain segment. The prospects for growing export potential are in the markets of frozen fish and crustaceans, vegetable oil, soybeans, meat products, and sugar.

\section{References}

[1] O.G. Charykova, V.F. Pechenevsky, M.E. Otinova et al, Exportoriented agri-food market in the conditions of transformation of the agrarian structure. Voronezh: FGBNU NIIEOAPK CCR of Russia, 2020, 198 p.

[2] P. Krugman, Strategic Trade Policy and New International Economics. Cambridge, MA: MIT Press, 1986, pp. 98-156.

[3] E. Helpman, P. Krugman, Trade Policy and Market Structure Cambridge, MA: The MIT Press, 1989, 191 p.

[4] M. Porter, The Competitive Advantage of Nations. New York: Free Press, 1990, $437 \mathrm{p}$.

[5] M. Otinova, T. Savchenko, "The development of a small agricultura business: trends and priorities", IOP Conf. Ser. Earth and Environmental Sci., vol. 274, p. 012039, 2019.

[6] A. Shamin, O. Frolova, V. Makarychev et al., "Digital transformation of agricultural industry", IOP Conf. Ser. Earth and Environmental Sci., vol. 274, p. 012029, 2019.

[7] L. Smutka, J. Spicka, N. Ishchukova, R. Selby, "Agrarian import ban and its impact on the Russian and European Union agrarian trade performance", Agricult. Econ. (Czech Republic), vol. 62, no. 11, pp. 493-506, 2016.

[8] A. Gibba, "Revealed comparative advantage and trade competitiveness in global vegetable products", Int. J. of Sci. \& Technol. Res., vol. 6, pp. 8-15, 2017

[9] V. Pechenevsky, G. Zakshevsky, "Prospects for the spatial development of agricultural production in the region", IOP Conf. Ser. Earth and Environmental Sci., vol. 274, p. 012008, 2019

[10] V. Maslova, N. Zaruk, M. Avdeev et al., "Competitiveness of agricultural products in the Eurasian Economic Union”, Agricult., vol. 9, no. 3, p. $61,2019$.

[11] V.V. Kolmakov, A.G. Polyakova, S.V. Karpova, A.N. Golovina, "Cluster development based on competitive specialization of regions", Reg. Econ., vol. 15, no. 1, pp. 270-284, 2019.

[12] V.G. Zakshevsky, O.G. Charykova, "Expanding competitive positions in the agro-food market: a regional aspect", Int. Agricult. J., vol. 5, no. 371, pp. 50-54, 2019.

[13] K.V. Ekimova, I.P. Saveleva, I.M. Tsalo, "Assessment of the impact of changes in world market conditions on regional processes", Reg. Econ., vol. 12 , no. 3 , pp. $670-683,2016$.

[14] D.A. Izotov, "Impact of foreign economic activity on the economic growth of Russian regions", Reg. Econ., vol. 14, no. 4, pp. 1450-1462, 2018 
[15] V.G. Zakshevsky, I.N. Merenkova, I.I. Novikova, E.S. Kusmagambetova, "Methodological tools for diagnostics of rural economy diversification”, Reg. Econ., vol. 15, no. 2, pp. 520-533, 2019.

[16] A.V. Turyansky, I.N. Merenkova, A.I. Dobrunova et al., "State support improvement for ecological land-use in terms of transition to rural territory sustainable development", Amazonia Investiga, vol. 175, no. 15, pp. 13-19, 2018

[17] L.G. Matveeva, O.A. Chernova, V.V. Klimuk, "Evaluation of the effectiveness of import substitution policy in industry: methodological tools, Izvestiya of Far Eastern Federal University", Econ. and Manag., vol. 3, no. 75, pp. 3-14, 2015.

[18] A. Ulezko, A. Tyutyunikov, A. Kurnosov, "Theoretical and methodological aspects of designing prospective models for agricultural development”, IOP Conf. Ser. Earth and Environmental Sci., vol. 274, 2019.

[19] M. Svanidze, L. Götz, I. Djuric, T. Glauben, "Food security and the functioning of wheat markets in eurasia: a comparative price transmission analysis for the countries of central asia and the south caucasus", Food Security, vol. 11, no. 3, pp. 733-752, 2019.

[20] T.N. Belova, "Import substitution processes in the agri-food sector", Reg. Econ., vol. 15, no. 1, pp. 285-297, 2019.

[21] D.A. Karkh, V.M. Gayanova, F. Aimel, "Priority directions for improving the efficiency of the regional food complex", Reg. Econ., vol. 2, pp. 260-271, 2015.

[22] O.B. Yarosh, E.A. Mitina, "Market of organic products in the region. Distribution channels and strategies for their development", Reg. Econ., vol. 16, no. 1, pp. 141-156, 2020 